\title{
The Impact of the Japanese Graduate Education System on the Experiences of International Students
}

\author{
Arikawa*, Tomoko \\ Center for International Education and Exchange, Osaka University, Osaka, Japan
}

Received April 1, 2021; Revised June 18, 2021; Accepted June 25, 2021

\section{Cite This Paper in the following Citation Styles}

(a): [1] Arikawa, Tomoko, "The Impact of the Japanese Graduate Education System on the Experiences of International Students," Universal Journal of Educational Research, Vol. 9, No. 8, pp. 1501 - 1510, 2021. DOI: 10.13189/ujer.2021.090802.

(b): Arikawa, Tomoko (2021). The Impact of the Japanese Graduate Education System on the Experiences of International Students. Universal Journal of Educational Research, 9(8), 1501 - 1510. DOI: 10.13189/ujer.2021.090802.

Copyright $\mathrm{C} 2021$ by authors, all rights reserved. Authors agree that this article remains permanently open access under the terms of the Creative Commons Attribution License 4.0 International License

\begin{abstract}
This paper examines how the experiences of international graduate students are influenced by the graduate education system applied in higher educational institutions in Japan. It is based on the author's ethnographic study on Indonesian students who studied in Japan from 1991 to 1992. The follow-up studies on the returnees after their study abroad were conducted from 2011 to 2013. The paper is likewise based on the author's work on international students at a Japanese university. This paper studied the experiences of Indonesian graduate students in the Science field with the graduate education system at Japanese universities. It focused on the koza research unit, which usually had the head professor and other faculty members in different ranks and the students in different years. The study found that this koza unit could be described as a "person-dependent" system, since the experiences of international graduate students differed depending on how the koza community was managed and practiced. For example, differences arouse from the variety in teaching methods and research learning among its members. This paper discusses the problems that arise when such system does not work from the perspective of international graduate students. Additionally, it discusses some possible improvements in overcoming the limitations of this system, while keeping the positive aspect of teaching and learning among its members. There are many higher educational institutions which seek globalization. This paper discusses the importance of international graduate students' perspectives in clarifying macro-level problems concerning the graduate education system of higher educational institutions.
\end{abstract}

Keywords International Graduate Students, Graduate Education System, Japan, Indonesia, Higher Education

\section{Introduction}

This paper examines how the experiences of international graduate students are affected by the graduate education system of higher educational institutions. It focuses on those international students studying at graduate programs that are in a different context from their undergraduate programs. This paper is based on the author's ethnographic study on Indonesian students who studied in Japan in the 1990s. It is also based on the follow-up studies in the 2010s on their later careers after returning to Indonesia. Furthermore, it is also based on the author's work on international students at a Japanese university.

This paper discusses some important issues concerning international students which continue until today. It examines the graduate education system in higher educational institutions through the influence it exerts on international graduate students.

\section{Past Literature on International Students}

\subsection{Past Research on International Students}

There has been extensive research on international 
students which analyzed various kinds of issues and problems especially since the latter half of the $20^{\text {th }}$ century (e.g., Altbach, Kelly, \& Lulat, [1]). Additionally, macro-level studies on higher education in relation with internationalization and globalization have taken place since around the 2000s (e.g., Altbach \& Knight, [2]; Knight, [3], [4]).

These past studies on international students and higher education examine either micro-level issues of international students and the macro-level system and policies of international education. Only a few studies look at the relations between macro-level problems and micro-level issues of international students. Additionally, less focus has been given on the diversity among international students. The different backgrounds of international students and the diversity in the contexts of higher educational institutions where they study have not been adequately examined.

There have also been some attempts to overcome the problems in past research concerning international students. For example, Bista [5] discussed that past studies looked at some aspects and parts of international students. He saw that not the overall picture of international students is seen, using "The blind Men and the Elephant" Parable (p. 1). Bista [5] also stated that in past literature, researchers looked at international students through "a deficit perspective" (p. 1). Such international students face problems and limitations as they go through experiences in various higher educational institutions. Bista [5] discussed the complexities among international students in their experiences. He likewise analyzed the problems in ignoring "human aspects" of international students. (p. 6).

Bista [5] and those who contributed to the book attempted to provide a bigger picture of international students' experiences. These include multiple perspectives, such as "sociocultural identities, contextual influences on learning experiences, wellbeing experiences, as well as post-study experiences" (p. 9).

They attempted to overcome the limitations in the past research on international students. However, those international students in the book are international students coming from non-English speaking countries to Western educational institutions. What happens then to international students who go to non-Western higher educational institutions? The context becomes different, just like the international students' experiences.

\subsection{Studies on International Graduate Students}

The different context and experiences of graduate students from those of undergraduate students are another issue of diversity among international students. There have certainly been some studies focusing on international graduate students' problems. For example, Tatiana Suspityna [6] studied the socialization of international graduate students. In her study, she examined how they make sense of their new world using organizational sense making with focus on cognitive aspects of international students. Suspityna stressed the importance of international graduate students making sense of their new worlds and changing their schemas.

So Hee Hyun [7] also performed a study using a qualitative approach to explore the academic and non-academic experiences of international graduate students in non-STEM fields at an American university. Hyun [7] found that those participants in the study focused on their academic life with academic-centered relationship. They did this while facing challenges regarding non-academic matters, such as managing stress and time, cultural and mental stress, and loneliness (pp. 59-61). However, they could pursue their degrees and gain academic success with a clear goal and motivation (pp. 60-61). Hyun [7] discussed the importance of understanding international graduate students' experiences "in a holistic perspective that reflect dynamic interaction between individual efforts and social-environmental influences" (p. 61).

There are other studies which look at the graduate students' experiences in a larger context. For example, Elliot, Baumfield, Reid, and Makara [8] focused on the "hidden curriculum." They positively used such curriculum in their studies on international graduate students as they pursue their doctoral studies in a different system than the system that they know of before their international study. They used an academic acculturation model based on Bronfenbrenner's bio-ecological theory (p. 737). They admitted the important roles of formal and informal support and academic curriculum and relationships at higher educational institutions in which international students have with their academic departments. They found the importance of support, curriculum, and relationships in the agency of international students as they take initiative and engage in the activities in new context. The hidden curriculum and the activities in it helped international students pursue their academic doctoral journey in the new system.

These studies are aligned with the significant aspects of Bista's [5] investigation on international students, highlighting the importance in more holistic perspectives. They also help us become aware of the importance of support, curriculum, and relationships in the agency of international graduate students who take initiatives and participate in various kinds of activities in the new context. Additionally, it is important to become aware of the non-academic context that international graduate students experience as they move from one system to another. The research contributes to explaining in a larger context the world of international graduate students from their perspectives. The same is looked into with various kinds of interactions on and off-campus. 


\subsection{Graduate Education System in Different Higher Education Contexts}

As explained in the previous sections, there have been past studies focusing on international graduate students. These researchers attempted to clarify the specific issues and problems particular to graduate students. Such issues and problems are different from those of undergraduate students. However, majority of those past studies are conducted in higher educational institutions in English speaking Western countries. It must be noted that the international students here are from non-Western countries. At the same time, there is an increase in the research of international students enrolled at universities in non-Western countries (e.g., Alemu \& Cordier [9], Pandiana, Baboob, \& Mahfoodha, [10]).

Different countries have different graduate education systems (e.g., Yudkevich, Altbach, \& de Wit, [11]). If the graduate education system itself is different, what will happen then to international students who are not familiar with the system? If the researchers are not aware of the differences in the graduate systems, they may not pay attention to the international graduate students' perspective from different graduate education systems in non-Western countries.

The differences in systems may closely relate with the lives and experiences of international students. The different context of the graduate education system, together with the varying backgrounds they had before their international study, may make international graduate students' lives and experiences different.

\subsection{The Limitations of the Extant Research on International Students}

It is now evident that previously conducted research on international students attended to specific issues at either the micro-level of individual students or at the macro-level of the systems and policies pertaining to the internationalization of higher education. Nevertheless, some extant studies have attempted to overcome the problems presented by such past studies (e.g., Bista [5]), and have examined the experiences of international graduate students more holistically and in wider contexts (e.g., Hyun [7], Elliot, Baumfield, Reid, and Makara [8]). However, limitations persist in the accumulated literature as these past studies have primarily focused on the sociocultural aspect of the experiences of international graduate students, and have not attended adequately to their experiences vis-à-vis the systemic facets of higher educational institutions.

This paper tries to overcome this gap in the extant research by examining how the graduate education system in Japan influences the lives and experiences of international graduate students. The paper is based on research previously accomplished by the author on Indonesian students in Japan. The next section describes the graduate education system and practices prevailing in Japanese universities. Subsequently, the paper elucidates the author's research methodologies and details the studied cases.

\section{Graduate Education System and Practice in Japanese Universities}

\subsection{Japanese Higher Education and the Graduate Education System}

Japanese higher education has attempted to model after the European system, especially that of German, education system since the late $19^{\text {th }}$ century, after Japan's Meiji Restoration. After World War II, Japanese higher education attempted to follow the American graduate and undergraduate education system (e.g., Amano, [12] pp. 21-23; Clark, [13] pp. 159-162). However, the old German style continued to influence Japanese higher educational institutions. For example, there are universities and faculties subscribing to the koza system. This system has some similarities with the German chair system. In both systems, research, teaching, and learning of research take place simultaneously (Clark, [14] pp. 46-49, pp. 130-131). The system is different from the department system (e.g., Coleman, [15] pp. 19-25; Yamanoi, [16] pp. 204-208). Although there have been changes in graduate education at Japanese universities especially since the 1990s, there are universities and faculties which continue to practice the koza system (e.g., Amano, [12] pp. 148-157; MEXT, [17]).

\subsection{Koza Research Unit: Community of Research Practice}

This paper calls the koza unit as the "community of research practice." It used the concept of "community of practice" by Lave and Wenger (Lave \& Wenger, [18]; Arikawa, [19]). Some characteristics of this community are, among others, the practice and activities in the community taking place among its members who have different experiences, expertise, and knowledge.

The head professor holds the most important power in research and management in each koza community (Clark, [13] pp. 167-169). In addition to the head professor, there are other faculty members, such as the associate and assistant professors, who are also responsible for teaching and advising students in the same community. The professor is in the center of the community, followed by associate professors and other academic staff. There are some koza communities which also have technicians who help with research and experiments of the members of the community. Each koza community also has students who in practice belong to this community. These include graduate students in doctoral or master's programs to 
undergraduate students in their junior or senior year, participating in various kinds of activities in the community.

\subsection{Koza Community for International Graduate Students}

When new international graduate students enter the graduate programs at Japanese universities as research students or degree-seeking students, they are assigned a supervising professor. Here each new international student enters the koza community of research practice, where the supervising professor is the head. New international graduate students become the new members of the community.

A new international graduate student starts the life as a novice in the community. Their activities include not only research and academic activities but also non-academic activities on daily basis. In such a community, not just the relationship with the supervising professor become important, but also the relationships among the members as well. As time passes every day at the community, new international graduate students gain experiences. They learn from the seniors in the community regarding research, research methods, and various kinds of academic and non-academic knowledge about the community. They gradually change their status from novice to seniors, who later on come to teach new members who start their lives in the community.

\section{4. "Person-Dependent" System in the Koza Community and International Graduate Students}

Having the above-described characteristics, this koza community can be characterized as a "person-dependent" system under the department. Actual practices and relationships become different, depending on the professor and other members in each community. There are also differences when it comes to research methods and practices. The experiences in the community greatly influence the life of international graduate students since the life of international graduate students are with their respective communities throughout their graduate programs.

If the community works well for international graduate students who seek advanced degrees, new graduate students will be able to learn about research, research methods, and engage in various kinds of activities in the community. Thus, senior members such as the professor, the associate professors, and senior students must be willing to help guide a novice, directly or indirectly. Through the process, they gain the expertise and move from being a novice to becoming senior members. As their lives in the community continue, they conduct research, publish papers, write dissertations, and finally obtain their doctoral degrees.

On the other hand, if this "person-dependent" system does not work, new international graduate students may face difficulties in the community. One knows it is not working if teaching and guidance are not working among its members, or faculty and senior members lack the perspective of teaching and learning of students in the community. A novice may not know what to do without knowledge of community, unless they are guided and supported, or somehow had managed to find solutions. In the worst case, they may be left on their own and may be isolated in the community.

\subsection{Changes in Graduate Education in Japanese Universities since the 1990s}

The problem of this person-dependent system in the koza community may be related with the history and practice of the koza system in Japanese higher education. Furthermore, it may also relate with the changes since the 1990s when graduate education has been focused on in Japanese universities.

In the past, the majority of those who went to graduate programs at Japanese universities were from the same undergraduate program and sought an academic career (e.g., Clark, [13] pp. 164-165). The number of graduate students was small. Such number may have enabled the apprenticeship style of teaching and learning among the members in koza communities.

The situation started to change especially since the 1990 s with the focus on graduate education and the increase in the number of graduate students ${ }^{1}$ (e.g., Huang, [20] pp. 319-322; Yamanoi, [16] pp. 159-161, pp. 289-310). Additionally, more students with diverse backgrounds come to graduate schools. Students who graduated from undergraduate programs in other Japanese universities and schools abroad likewise come to graduate schools (e.g., Huang, [20] pp. 336-337).

In the 2010s, reflections and discussions were made on graduate education in the past 20 years (e.g., MEXT, [17]). The discussions included the problems concerning the decrease in the number of those who seek doctoral programs and the increase in the number of students in proportion to the university faculty members especially at research universities (MEXT, [17] pp. 6-7).

\section{Different Graduate Experiences in Koza Community at Japanese Universities}

Based on the author's past research, the experiences of

1 The number of those local students who entered the doctoral program after taking their Master's degree started to decrease after its peak of 12,000 in 2003. It became 6,000, which is about half, by 2018 (MEXT, [21]). The problem is also related with other problems of higher educational institutions regarding faculty positions, such as fewer faculty members having stable positions (e.g., Amano, [12] pp. 148-157; Yamanoi, [16] pp.289-312, MEXT, [17] p. 6). 
Indonesian graduate students in different koza communities and contexts are introduced in the following sections. The descriptions focus on learning about research practice and the relationships among the members in their respective communities. The author's research method will be explained before introducing the cases.

\subsection{Research Method}

The author specializes in Educational Anthropology, and thus took an ethnographic approach to this study of international students. The author selected one group of international students for the study: the Indonesians. Researchers performing ethnographic studies generally undertake fieldwork over an extend period such as a year. The fieldwork comprises participants' observations and interviews using the native language of subjects. The author conduced fieldwork with Indonesian students enrolled at Japanese University A ${ }^{2}$ between 1991-1992 to attain an intensive understanding of the world of Indonesian students in Japan from their perspectives. The author used the Indonesian language to explore how the students learn new knowledge and practices in Japan. Moreover, the author learned how they keep and use their own practices which they had brought from Indonesia.

\subsubsection{Fieldwork from 1991 to 1992}

The author performed participants' observations during fieldwork conducted between 1991 and 1992, using the Indonesian language to examine the on and off-campus of the Indonesian students. The author engaged in the participant activities related to the koza community after obtaining the requisite permissions from Indonesian students who agree to take part in the study and their respective supervising professors. The author participated and observed daily in the first informant's koza community for about a month. After learning about the lives and relationships pertaining to the first informant's koza, the author performed subsequent similar month-long participant observations at the koza communities of the second, third, and fourth informants in turn. These intense participant observations allowed the author to learn about and compare the practices and daily interactions of the koza communities from the perspective of each informant. The author informally interviewed every informant while engaging in the activities of each koza community. On weekends, the author participated in the off-campus activities of those informants, joining them as they went out with friends or attending events organized by the Indonesian students' association.

The author examined the similarities and differences

2 All the names of universities and persons in this paper are changed to protect their identities and privacy. There were 21 Indonesian students who studied at University A as of May 1992. among the participating students through these intensive observations of the four informants and their respective koza communities. In addition, the author explored the factors that could have influenced the noted similarities and differences. During the latter part of the fieldwork, the author conducted interviews with other Indonesian students, focusing on the issues and points determined to be significant from the earlier intensive participant observations. The author continued to participate in the off-campus activities of Indonesian students throughout the period.

The author took daily detailed fieldnotes for entire duration of the fieldwork. These notes were examined in detail during the analyses, issues that became apparent through the participant observations and interviews were categorized and evaluated. The author found that koza community was a critical aspect of the lives of Indonesian graduate students. This paper introduces the cases pertaining to the relationships of two informants with their koza community.

\subsubsection{Follow-up Studies in 2013}

After the fieldwork, the author continued to conduct follow-up studies in Japan and later in Indonesia after they returned to the country. In the follow-up studies in Indonesia from 2011 to 2013, the author interviewed the returnees who studied abroad. In the follow-up study at University $T$ in 2013, the author interviewed those who had studied in other countries. Such is in addition to those who studied in Japan, reaching a total 16 faculty members.

The author examined similarities and differences in their graduate experiences and the influences of the same in their careers in Indonesia. These follow-up studies made the author aware of the different graduate education system. Such system continued to influence returnees who took academic careers at universities in Indonesia.

The interview questions examined matters such as their research life as international graduate students, their relationships, and the system of graduate study. The open-ended interviews explored the issues that emerged from the responses provided by the informants. On average, each interview lasted between thirty minutes and one hour.

This paper outlines the results of the follow-up study conducted with two informants who studied in Japan, focusing on their respective experiences with their koza communities in Japan.

\subsubsection{Differences in the Research Methodologies of the Two Studies}

It has previously stated that there were differences in the research methodologies employed in the first two cases and in the subsequent two cases. The first two cases were taken from the author's fieldwork, during which the author observed and participated in the activities 
undertaken by the informants in the initial phase of their graduate studies. The informants discussed their specific relationships and the daily occurrences and experiences in their koza communities. Conversely, the latter two cases are introduced from the author's follow-up studies, for which the author interviewed graduate students who had completed their international study in Japan and had returned home to Indonesia. These informants were asked to reflect on their encounters and relationships with their koza community, among other issues.

Although different in context and time, all four cases discussed in this paper pertain to Indonesian students who studied in Japan. They demonstrated the diversity of the experiences of individual Indonesian graduate students depending on the koza community to which they belonged while they studied in Japan.

\subsection{Cases of Graduate Experiences in Japan}

Based on the author's past research as described above, the four cases are introduced from Indonesians who studied in Japan. The first two cases ${ }^{3}$ are from the fieldwork at University A in Japan. These are the stories about the relationships and activities of two Indonesian graduate students during their early days in koza communities. This is then followed by two cases from the follow-up studies in Indonesia. Two returnees reflect on their past experiences in their doctoral program in their koza communities. All four Indonesians majored in Science field at graduate programs in Japanese universities.

\subsection{1. $\mathrm{Pak}^{4}$ Zainal and His Senior}

Pak Zainal entered University A as a research student during fall of 1991. Half a year later, he entered the Master's program in spring of 1992. In his early days, Pak Zainal tried to follow the practices of his koza community. The members went out to eat lunch and dinner together in the cafeteria. He went out with them. After his family came to Japan in the spring of 1992, he went back home for dinner, and came back and stayed in the office until other members went home. If the koza members stayed in the office until 8:00 or 8:30 pm and went home without taking dinner together, he stayed until the other members left. To him, it was important to practice the same routine and stay in the office for the same number hours with other members.

The koza community which Pak Zainal belonged to has the system of teaching and learning among its members. In his first year, the senior student Shonai-san ${ }^{5}$ taught Pak

3 The first two cases from the Japan fieldwork are based on the author's original research and publication in Japanese (Arikawa, [22]).

4 "Pak" was used before a male's name in Indonesia if the person is older and should be called in a formal manner.

5 "-san" was added after a person's name to call other koza members in a polite manner.
Zainal how to conduct an experiment and how to use equipment. Pak Zainal got along with this senior who was easy to talk to and could speak some English. The senior was sent from the company for the graduate degree. Pak Zainal could consult with this senior easily if he had problems.

However, Pak Zainal was assigned a new topic of research and a new senior when he entered the Master's program in Spring of 1992. The new senior, Nishi-san, was quiet and he only spoke in Japanese. Nishi-san would do the experiment by himself without calling Pak Zainal. Thus, it became difficult for Pak Zainal to learn how to conduct experiments. Pak Zainal became concerned because when this senior graduate, Pak Zainal himself would become a senior. Seniors shall be the ones responsible of the equipment and teaching the juniors.

\subsubsection{Pak Taufik and His Senior in the Same Office}

Pak Taufik entered the Master's program in Engineering at University A in fall of 1989. He entered after half a year of learning the Japanese language course. During the time of his Master's program, Pak Taufik was able to ask questions to a doctoral student, Gotanda-san, who shared the office. Pak Taufik had to do research and conduct experiments by himself. He had the associate professor with whom he could consult. However, for Pak Taufik Gotanda-san could communicate in English and was much easier to talk to. Thus, Pak Taufik had a close relationship with Gotanda-san.

His koza community had teatime in the afternoon daily where all the members joined. One member of the community would call in the office. Initially, Pak Taufik joined the teatime, but he eventually decided not to join. His research was not going well and he was not comfortable speaking in Japanese.

\subsubsection{Pak Kartika}

Pak Kartika first participated in a Japanese language course for half a year before entering the doctoral program at University B in fall of 2006. After his entrance to the koza community, he liked the community's atmosphere. All the graduate students in his community helped each other in research. The professor was strict and there were Japanese members who were also strict. Furthermore, international students, including him, also attempted to fit in the community.

The research discussions were sometimes with the professor and often among the students. There was an associate professor who would advise Pak Kartika regarding research and writing papers. He used both Japanese and English in the discussions. There was a seminar every week and everyone had to attend it. The students had to present in the seminar, twice in each semester.

Every day the members of the koza community went to lunch and dinner together. The community also had 
teatime daily. The sensei ${ }^{\underline{6}}$ joined about half of the community's activities every day. Pak Kartika went to the lab at 7:00 or 8:00 am and stayed there until the sensei went home.

Going to lunch and having tea together with the community members helped Pak Kartika greatly. When he had some research problems, talking with other members helped him. Even if the discussions did not touch on the issue directly, it still helped him find other ways to solve the problems.

Regarding his research, the sensei had a big project. Pak Kartika worked on some parts of the project. His research went well. He was able to publish in journals and present in conferences. Pak Kartika finished the doctoral program in three years.

\subsubsection{Pak Supriyanto}

Pak Supriyanto did not have to study Japanese language ${ }^{7}$ to enter the doctoral program at University C in 2007. Those who entered from master program had to study Japanese language. However, those in doctoral programs did not have to study Japanese.

By the end of his first year, the professor who was his supervisor retired. Two professors, Matsuyama-sensei, the professor, and Toki-sensei, the associate professor, came to Pak Supriyanto's koza community. The students in the community had discussions with the sensei in English if they could not speak in Japanese.

Pak Supriyanto needed help on his research from other students in the master's program. Toki-sensei was in the lab to watch their work. Pak Supriyanto had to use Japanese with other students. However, if there were problems, Toki-sensei helped him. Pak Supriyanto went to the lab at 7:00 am and stayed there until 10:00 or 11:00 $\mathrm{pm}$. He went there even on Sundays.

He used the equipment in research, which he had the experience of using when he worked with similar ones when he was in another company in the past. He was able to use the equipment since it had the same basic concept. There were seminars once every week and everyone had to attend it.

There were also parties in the koza community. He had juice, while others drank alcohol. No one forced him and the sensei understood his religion, so the sensei always chose fish for him. The koza cooperated with companies and had chances to meet the said companies' members. He had good relations with his seniors and the sensei. Their relationships continued after he finished his doctoral program in three years. He returned to Indonesia

6 "sensei" was used by the students to refer to the faculty members, sometimes after the faculty's name. Here Pak Kartika referred to his associate professor as "sensei". Pak Kartika also explained that his koza also had tennis parties, where the members stayed overnight and played tennis together.

7 Pak Surpriyanto said that he learned to use Japanese in meetings and in doing things with his neighbors in the public housing where he lived with the family. afterwards.

\section{Discussions}

\subsection{Person-Dependent System of Learning Research in Koza Communities}

Koza communities have a basically similar system $^{8}$ with a head professor and other faculty members in different ranks. They also have students from different years in undergraduate to graduate programs. International graduate students' experiences were different depending on the professor and faculty members, other students, and practices in the koza community, as the cases have shown. This is in addition to research fields and research methods.

Every year there are usually changes in the memberships in these koza communities. Some students graduate and those students who had stayed in the community in the previous year were supposed to have gained the experience on research and non-academic activities in the community. Moreover, as the faculty moves or retires, new faculty members come in the community. There is likewise a change in the head professor which influences the practice and relationships among the members in the koza community.

Those cases of two returnees show that koza community works well, in which the members helped each other in research. In Pak Supriyanto's case, his professor watched to see how the master student helps in his research. If there were problems, the professor was able to help solve the problem. It showed the importance of faculty member's involvement and supervision in the student's research.

\subsection{Person-Dependent System for International Graduate Students}

On the other hand, international graduate students could face some problems concerning the learning of research and the relationships that come from the koza community's person-dependent system. If an international student does not know about the system nor about other people and communities, it may take time to find out what the problem is. They may think it is their own problem and not that of the koza community. As such, they struggle in solving the problem alone. Even if they become aware of the problem in the community, it may be difficult for a student to speak it up. Those outside of the koza community may not be aware of what is happening inside the community.

The solution will basically rely on the koza community and the people concerned in this person-dependent system.

8 There are faculties which have more than one professor in one koza, with the change in the koza system in Japanese universities. 
Both professors and students in the community must be involved. If the student who has some problems consults with the professor, and if the professor becomes aware of the problem and tries to solve it, the solution may work. If the problem is not solved inside the community, and if the department, faculty, or other system becomes aware of the problems, the situation may change, depending on who and how those concerned would work to solve the problem. If the koza community cannot solve the problems inside, and the outside system cannot solve the problem, as well, then the situation may become serious.

Their experiences in koza community were critical and represented the most challenging aspect of their lives as international graduate students. Their encounters within the koza were closely related to the supervision they attained from their professors and other senior members of the koza. In addition, experiences associated with the koza could have influenced the process of the research they performed during their graduate programs. Further, their experiences with the koza could be closely related to their goals of obtaining advanced degrees.

\subsection{Improvement in the System of Research Learning for Graduate Students}

We have been discussing the problems of koza communities in its person-dependent system from international graduate students' perspectives. The problem becomes more apparent with more diverse international graduate students when it comes to their backgrounds and experiences.

The independence of each koza community may work as far as all the koza communities work well inside each community for all students. From international graduate students' perspectives, the community works well when the learning of research takes place. Here they can conduct research, and their research progress is supplemented with the appropriate supervision and guidance, in good relationships among its members in the community.

Considering the diversities in practice and relationships in the koza community with the person-dependent system, how could the same be improved? The following discussions are based on the assumptions that graduate programs of the universities accept those qualified graduate students with diverse backgrounds and those without enough backgrounds in the major and research fields of the academic discipline. It is difficult to teach everything to new members of the koza community independently. This is true especially if there are more new members than the number of senior members.

One option would be to provide some kinds of learning opportunities on some basic courses of research and research methods to all new graduate students without enough backgrounds. Each new student starts his/her actual research work at each koza community after completing those courses as introduction on research.

In other words, all incoming graduate students will have a minimum standard of learning and experience on research, regardless of the koza community they belong to. This would also mean releasing the burden of each koza community from doing all the work for their new students.

Some faculties and departments may have already taken some measures to alleviate the problem. However, it is important to make this issue of teaching and learning at graduate education systems more open. It is likewise important to try to solve the problem at the macro-level of the said system. Additionally, it is important to provide advising and guidance to all students. However, it needs to be made more open and check system needs to see the quality of supervision by the professors and other members in the koza community.

We have been discussing this issue from international graduate students' perspective. A brief mention will be made on a different point of view. It is also important to check the environment and conditions on faculty and senior members in the koza community. For example, it is crucial to check whether there is too much work given to faculty members, and those senior year graduate students getting too many responsibilities in taking care of too many new members in the community. If these situations continue in the koza community, it may become difficult to conduct research and aid each other in research. Therefore, the key practice in the koza community will be lost.

Graduate education is one of the most essential activities of higher education. They are linked closely to higher education research. It is important to focus less on the person-dependent system, while keeping the positive aspects of the koza community such as teaching and learning among the community members. Moreover, it is essential to overcome the boundary of each koza community since it faces the change in graduate education and in the number and kinds of graduate students.

Solving the problems of the person-dependent system will depend on how improvements university-wide as well as within the faculty and departments will take place. The issue from the perspectives of international graduate students will help clarify the problems in the graduate education system and help improve the system. The improvement will be helpful not only for international graduate students but also for all graduate students and those concerned with graduate education in Japanese universities.

\section{Summary and Conclusions}

This paper examined how the international graduate students' experiences at the micro-level are influenced from the graduate education system at the macro-level. 
The present study is based on the author's research since the 1990s until today. Individual students make decisions on international study through their own reasons and motivations. At the same time, there are many factors, which affect individual students' decisions and experiences in their study abroad. Pandemics and health concerns such as the COVID-19 is one of them.

There have been many changes taking place in Japanese higher educational institutions. There are macro-level issues and problems on graduate education system which need to be examined from international graduate students' perspectives if higher educational institutions are to internationalize and globalize.

It is important to examine the experiences of international graduate students not only at the individual level, but also those issues related to the graduate education system at the macro-level. Apart from the problems related to personal issues, there are international students' experiences which may be related with the graduate education system of higher educational institutions. It is therefore important to find out and clarify the problem.

It is also crucial to discuss the necessary measures for improvement. If universities become aware of the problems and try to develop the system, it may provide an improvement of the graduate education for students and higher educational institutions.

\section{Acknowledgements}

The author greatly appreciates the efforts made by the anonymous reviewers of the manuscript, whose valuable insights helped the author immensely in improving the quality of this paper.

\section{REFERENCES}

[1] Altbach, P. G., Kelly, D. H., \& Lulat, Y. G-M., Research on foreign students and international study: An overview and bibliography. New York: Praeger, 1985.

[2] Altbach, P. G. \& Knight, J. "The internationalization of higher education: motivations and realities," Journal of Studies in International Education, vol. 11 no. 3/4, Fall/Winter, pp. 290-305, 2007. https://doi.org/10.1177/10 28315307303542

[3] Knight, J., "Education hubs: A fad, a brand, an innovation?," Journal of Studies in International Education, vol. 15 no. 3, pp. 221-240, 2011. https://doi.org/10.1177/102831531139 8046

[4] Knight, J. (Ed.), International education hubs: student, talent, knowledge-innovation models. Springer, Dordrecht, 2014.

[5] Bista, K., "Exploring the field: Understanding the international student experience," in Bista, K., (Ed.), Global Perspectives on International Student Experiences in Higher Education: Tensions and Issues, pp. 1-15, New York \& London: Routledge, 2019.

[6] Suspitsyna, T., "Socialization as sensemaking: a semiotic analysis of international graduate students' narratives in the USA," Studies in Higher Education, vol. 38, no. 9, pp. 1351-1364, 2013. http://dx.doi.org/10.1080/03075079.201 1.629343

[7] Hyun, S. H., "International graduate students in American higher education: Exploring academic and non-academic experiences of international graduate students in non-STEM fields," International Journal of Educational Research, vol. 96, 56-62, 2019. DOI: 10.1016/j.ijer.2019.05.007

[8] Elliot, D., L., Baumfield, V., Reid, K., \& Makara, K. A., "Hidden treasure: successful international doctoral students who found and harnessed the hidden curriculum," Oxford Review of Education, vol. 42, No. 6, pp. 733-748, 2016. DOI: $10.1080 / 03054985.2016 .1229664$

[9] Alemu, A. M. \& Cordier, J., "Factors influencing international student satisfaction in Korean universities" International Journal of Educational Development, vol. 57, pp. 54-64, November 2017. https://doi.org/10.1016/j.ijedu dev.2017.08.006

[10] Pandiana, A., Baboob, S. B., \& Mahfoodha, O. H. A., "Influence of multiculturalism on the study programs in Malaysian public universities: international students' perceptions," Studies in Higher Education, 2016, vol. 41, no. 7, pp. 1133-1152, 2016. http://dx.doi.org/10.1080/030750 79.2014.968538

[11] Yudkevich, M., Altbach, P. G., \& de Wit, H. (Eds.), Trends and issues in doctoral education: A global perspective, New Delhi, India: Sage, 2020.

[12] Amano, I. Daigaku kaikaku no shakaigaku (Sociology of University Reform). Tokyo: Tamagawa Daigaku, 2006.

[13] Clark, B. R., Places of inquiry: Research and advanced education in modern universities. Berkeley \& Los Angeles, CA: University of California Press, 1995.

[14] Clark, B. R., The higher education system: Academic organization in cross-national perspective. Berkeley \& Los Angeles, CA: University of California Press, 1983.

[15] Coleman, S., Japanese Science: From the Inside. London and New York: Routledge, 1999.

[16] Yamanoi, A., Nihon no daigaku kyoju shijou (Academic marketplace in Japan). Tokyo: Tamagawa Daigaku, 2007.

[17] MEXT, "Mirai wo kenin suru daigakuin kyoiuku kaikakushakai to kyoudou shita "chi no purofesshonaru" no ikusei(shingi matome) " (Reform of Graduate Education leading the future: Nurturing "knowledge professional" who can collaborate with society (Summary of discussions)), Chuou kyouiku shingikai daigaku bunkakai (Committee on Higher Education, Central Education Council)), heisei 27 nen (2015 nen) 9 gatsu $15 \mathrm{hi}$ ) (September $\left.15^{\text {th }}, 2015\right), 2015$ (https://www.mext.go.jp/component/b_menu/shingi/toushi n/_icsFiles/afieldfile/2016/02/09/1366899_01.pdf) (accessed March 22, 2021) 
[18] Lave, J. \& Wenger, E., Situated learning: Legitimate peripheral participation, Cambridge: Cambridge University Press, 1991.

[19] Arikawa, T., "The Long-term Impact of International Study: Indonesian Graduate Students in Japan and Their Subsequent Academic Careers in Indonesia," Universal Journal of Educational Research, vol. 7, no. 8, pp. 1756-1764, 2019. DOI: 10.13189/ujer.2019.070814

[20] Huang, F., "From quantitative expansion to qualitative improvement: Changes in doctoral education in Japan," in Yudkevich, M, Altbach, P. G., \& de Wit, H. (Eds.), Trends and issues in doctoral education: A global perspective, pp. 316-339, New Delhi, India: Sage, 2020.
[21] MEXT, Daigakuin kyoiku no arikata ni tsuite no ronten, daigakuin no ryoteki kibo ni kansuru kangaekata ni tsuite (Issues on graduate education: Ways of thinking regarding the quantitative scale of graduate education), Chuou kyoiku shingikai daigaku bunkakai daigakuin bukai (Subcommittee on Graduate Education, Committee on Higher Education, Central Education Council), (dai 87 kai $\left(87^{\text {th }}\right.$ meeting)) shiryou 2 (Material 2) H30. 8.6. (August, $6^{\text {th }}$, 2018), 2018 (https://www.mext.go.jp/content/1423015_00 3.pdf) (accessed March 18, 2021).

[22] Arikawa, T., Nihon ryugaku no esunografi (Ethnography of study in Japan). Osaka University press, 2016. 